\title{
Motivatie, leerstrategieën en voorkeur voor doceerbenadering van honoursstudenten in het hbo
}

\author{
Elles Kazemier, Johan Offringa, Lilian Eggens \& Marca Wolfensberger*
}

\begin{abstract}
Deze studie verkent wat hbo-honoursstudenten, vergeleken met reguliere studenten, belangrijk vinden in de benadering door hun docenten. Honoursstudenten vragen volgens de literatuur om een andere doceerbenadering dan reguliere studenten, omdat ze meer uitdaging willen en aankunnen. Vanuit de veronderstelling dat hbo-honoursstudenten beschikken over een relatief hoge motivatie en goed ontwikkelde leerstrategieën, is de relatie tussen motivatie, leerstrategie en docentvoorkeur onderzocht. Met vragenlijstonderzoek $(N=194)$ is nagegaan hoe tweedejaars honours- en reguliere studenten van de Hanzehogeschool Groningen zichzelf beoordelen op motivatie en leerstrategie en hoe zich dat verhoudt tot hun voorkeur voor een doceerbenadering.
\end{abstract}

Honours- en reguliere studenten scoren zichzelf significant verschillend: honoursstudenten zeggen meer intrinsiek gemotiveerd te zijn, meer waarde aan hun studie te hechten en meer te vertrouwen op hun eigen kunnen. Daarnaast beoordelen ze hun vermogen tot kritisch denken en tot metacognitieve zelfregulatie hoger dan reguliere studenten dat doen. Honoursstudenten tonen een sterkere voorkeur voor docenten die in hun benadering kritisch en integratief denken, actief leren en zelfregulatie bevorderen. Er is geen overtuigend bewijs gevonden voor de verwachting dat motivatie en leerstrategieën van honoursstudenten de voorkeur voor een zelfregulatie-bevorderende docent voorspellen.

\section{Inleiding}

In het Nederlandse hoger onderwijs hebben excellentieprogramma's het laatste decennium een hoge vlucht genomen. Ook de Hanzehogeschool Groningen biedt sinds 2010 op grote schaal honoursprogramma's aan: extracurriculaire selectieve programma's van dertig studiepunten die zich richten op professionele excellentie, in de meeste gevallen tijdens de hoofdfase van de bachelor. Ze bevatten verbredende en verdiepende onderdelen en besteden daarmee aandacht aan zowel de persoonlijke als de professionele ontwikkeling van de studenten. Honourspro-

* $\quad$ E. M. Kazemier, MA, MEd (e.m.kazemier@pl.hanze.nl) is werkzaam bij het Instituut voor Bedrijfskunde en het lectoraat Excellentie in Hoger onderwijs en Samenleving, Hanzehogeschool Groningen. G.J. Offringa, MSc is werkzaam bij het Instituut voor Facility Management en het lectoraat Excellentie in Hoger Onderwijs en Samenleving, Hanzehogeschool Groningen. Dr. L. Eggens is werkzaam bij de Academie voor Gezondheidsstudies, Hanzehogeschool Groningen. Dr. M.V.C. Wolfensberger is werkzaam bij het lectoraat Excellentie in Hoger Onderwijs en Samenleving, Hanzehogeschool Groningen en bij de Faculteit Geowetenschappen, Universiteit Utrecht. 
gramma's richten zich op studenten die meer willen en meer kunnen dan het reguliere programma biedt en daarom spelen motivatie en - in de propedeuse geleverde - prestaties een belangrijke rol in de selectie van honoursstudenten. Maar wat vraagt een student die meer uitdaging zoekt, nu eigenlijk van zijn docenten?

In deze studie zijn de motivatie, leerstrategieën en doceerbenaderingsvoorkeur van honoursstudenten vergeleken met die van reguliere studenten. Daarnaast is verkend hoe motivatie en leerstrategieën van honours- en reguliere studenten zich verhouden tot hun voorkeur voor doceerbenadering en -strategieën.

\section{Probleemstelling, praktische relevantie en theoretisch kader}

\section{Achtergrond en relevantie}

In het honoursonderwijs is voor docenten een sleutelrol weggelegd als katalysator van talentontwikkeling (Renzulli, 2008). De toename van honourstrajecten geeft een groeiend aantal docenten een nieuwe uitdaging: honoursstudenten blijken een andere benadering te vragen dan reguliere studenten (Scager, 2008; Wolfensberger, 2012). Parallel aan de groei van dergelijke programma's neemt het belang van wetenschappelijk onderbouwd inzicht in effectieve doceerstrategieën voor gemotiveerde en getalenteerde studenten in het hoger onderwijs toe. Onderzoek naar doceer- en leerstrategieën (Biggs, 1996; Trigwell, Prosser, \& Waterhouse, 1999) neemt meestal het docentperspectief als uitgangspunt, terwijl er relatief weinig aandacht uitgaat naar de beleving door studenten (Hativa \& Birenbaum, 2000). Uit onderzoek naar het docentperspectief op honoursonderwijs blijkt dat docenten over het algemeen veel ruimte bieden aan honoursstudenten, hoge eisen aan hen stellen en van hen verwachten dat zij zich inspannen om zelfstandig en actief te leren (Wolfensberger, 2012). Het is echter nog niet empirisch aangetoond of deze aanpak aansluit bij de motivatie en leerstrategieën van honoursstudenten in het hbo. Achterberg (2005) bepleit bovendien instellingsspecifiek onderzoek naar verschillen tussen honours- en andere studenten om een afwijkende pedagogische en curriculaire aanpak voor honoursstudenten te rechtvaardigen. De doelstelling van dit onderzoek is dan ook om de relaties tussen motivatie, leerstrategie en voorkeur voor doceerbenadering van honoursstudenten binnen het hbo te onderzoeken. Een vergelijking met de kenmerken en voorkeuren van reguliere studenten kan meer inzicht geven in mogelijke verschillen tussen doceerbenaderingen voor honours- en reguliere studenten.

\section{Motivatie en leerstrategieën}

Honoursstudenten beschikken over een hoge motivatie, nieuwsgierigheid en leervermogen (Scager, 2008). Motivatie kan zowel een extrinsieke als intrinsieke oriëntatie hebben, afhankelijk van de overweging waaruit een student een leertaak uitvoert. Studenten die extrinsiek georiënteerd zijn, ondernemen een taak vanwege cijfers, beloningen, prestaties, oordelen van anderen of competitie, terwijl een intrinsieke oriëntatie zich richt op uitdaging, nieuwsgierigheid en mees- 
terschap (Pintrich, Smith, Garcia, \& McKeachie, 1991; Ryan \& Deci, 2000). Motivatie wordt, naast doeloriëntatie, onder andere beïnvloed door de waarde die iemand toekent aan een taak ( task value) en door self-efficacy, de verwachting om een taak succesvol te kunnen volbrengen vanuit opvattingen over aanwezige kennis en vaardigheden (Pintrich et al.; 1991). Eerder onderzoek dat motivatie, leerstrategie en docentvoorkeur van reguliere studenten aan elkaar verbindt (Hativa \& Birenbaum, 2000) laat een positief effect zien van taakwaardering en selfefficacy op de mate van intrinsieke motivatie. Kaczvinsky (2007) toonde aan dat honoursstudenten vergeleken met reguliere studenten niet alleen gemotiveerder zijn, maar ook meer intellectuele interesse hebben en een groter vertrouwen in hun eigen vaardigheden. Dit alles leidt tot de veronderstelling dat hbo-honoursstudenten zich onderscheiden van reguliere hbo-studenten door een hogere intrinsieke motivatie, een hogere taakwaardering en een hogere self-efficacy.

Behalve op motivatie worden honoursstudenten aan de Hanzehogeschool geselecteerd op hun studieprestaties. Studieprestaties kunnen opgevat worden als de uitkomst van leervermogen en daarmee van (meta)cognitieve vaardigheid. Volgens Pintrich et al. (1991) helpen cognitieve strategieën de student om kritisch te denken, opgedane kennis toe te passen in nieuwe situaties en de eigen ideeën kritisch te evalueren. Metacognitieve, zelfregulerende strategieën helpen de student in zijn kennisverwerving door bewustzijn van kennis en controle over cognitie. Begaafde mensen beschikken over beter ontwikkelde cognitieve en metacognitieve strategieën (Pintrich et al., 1991) en ontwikkelen expertise sneller en/of op een hoger niveau dankzij hun diepe benadering van leren (Sternberg, 2001).

Honoursstudenten worden niet alleen verondersteld te beschikken over een hoger leervermogen; ze vragen ook om een minder voorgestructureerde aanpak (Scager, 2008; Wolfensberger \& Offringa, 2012). Over de behoefte aan autonomie en de bereidheid tot zelfregulerend leren is bekend dat deze positief worden beïnvloed door intrinsieke motivatie (Pintrich et al., 1993; Zimmerman \& Schunk, 2012). De veronderstelling is daarom ook dat hbo-honoursstudenten zich van reguliere studenten onderscheiden door een hogere mate van kritisch denken en van zelfregulerend leren.

Als hbo-honoursstudenten inderdaad beschikken over een hogere motivatie, een hoger vermogen tot kritisch denken en zelfregulatie en daarmee over een diepere benadering van leren, wat vraagt dat dan van de benadering door hun docenten?

\section{Doceerbenadering}

Wanneer studenten ervaren dat een doceerbenadering aansluit bij hun eigen benadering van leren, leren ze met meer succes en met meer plezier (Hativa \& Birenbaum, 2000). Studenten die intrinsiek gemotiveerd zijn en diepere leerstrategieën hanteren, zijn gebaat bij een docent die aansluit bij hun diepere benadering van leren (Entwistle \& Tait, 1990). Onderzoek onder ervaren honoursdocenten laat zien dat zij afwijken van traditionele onderwijsmethoden en hun honoursstudenten meer uitnodigen om actief te participeren (Wolfensberger, 2012). Hun aanpak biedt ruimte, is minder voorgestructureerd en geeft de stu- 
ring van het leerproces meer over aan de honoursstudenten zelf, waarbij de docent vooral optreedt als begeleider die stimuleert om verbanden te leggen (Scager, 2008; Wolfensberger, 2012).

Hativa \& Birenbaum (2000) onderzochten onder reguliere studenten de voorkeur voor een doceerbenadering op basis van vier verschillende benaderingen. Binnen de docentgecentreerde benadering onderscheiden zij:

- de docent die informatie overdraagt (information-imparting).

Een docent die deze benadering hanteert, behandelt veel stof in elke les en bestrijkt het voorgeschreven cursusmateriaal op die manier zo volledig mogelijk, zodat studenten goede aantekeningen kunnen maken. Hij focust op feiten of op vaardigheden en past tempo en niveau van informatieoverdracht niet aan de verschillen tussen de studenten aan.

- de docent die zowel duidelijk als interessant is (clear-interesting).

Een docent met een 'duidelijk-interessante' benadering geeft de lesstructuur aan en verbindt nieuwe onderwerpen aan die structuur, aan eerdere leerstof en aan de (voor)kennis van studenten. Hij vat samen, geeft voorbeelden, beantwoordt vragen en herhaalt totdat iedereen de stof begrijpt. Hij stimuleert de nieuwsgierigheid van studenten naar het onderwerp en is enthousiast, humoristisch en gevarieerd.

Binnen de studentgecentreerde benadering onderscheiden Hativa \& Birenbaum:

- de faciliterende docent (providing)

In de faciliterende benadering moedigt de docent studenten aan die zijn vak lastig vinden. Hij toont begrip en geeft om hun slagingskansen. Hij moedigt studenten aan samen te werken om de stof beter te begrijpen en om hem te benaderen met vragen als dat niet lukt. Hij besteedt aandacht aan effectieve studiestrategieën

- de zelfregulatiebevorderende docent (self regulation-promoting).

De docent die zelfregulatie bevordert, moedigt studenten aan om kritisch te zijn over de opvattingen die hij presenteert en om hun eigen creatieve ideeën te vormen. Hij vindt integratie van gezichtspunten en kennis uit verschillende bronnen belangrijk en vraagt om zelfstudie van studenten. Succes is afhankelijk van de inspanning die studenten leveren. Hij zorgt voor actieve deelname aan zijn les.

Over het algemeen prefereren studenten in het onderzoek van Hativa \& Birenbaum de duidelijk-interessante benadering, terwijl de informatieoverdragende benadering en de zelfregulatiebevorderende benadering het minst de voorkeur kregen. Ook blijkt de voorkeur voor een bepaald type doceerbenadering te worden beïnvloed door de motivatie en leerstrategieën van de student. Studenten die een sterke voorkeur hebben voor een docent met een duidelijk-interessante benadering, scoren hoog op extrinsieke motivatie en laag op kritisch denken. De beperkte groep studenten die een zelfregulatiebevorderende docent prefereert, kenmerkt zich door een hoge intrinsieke en een lage extrinsieke motivatie. 


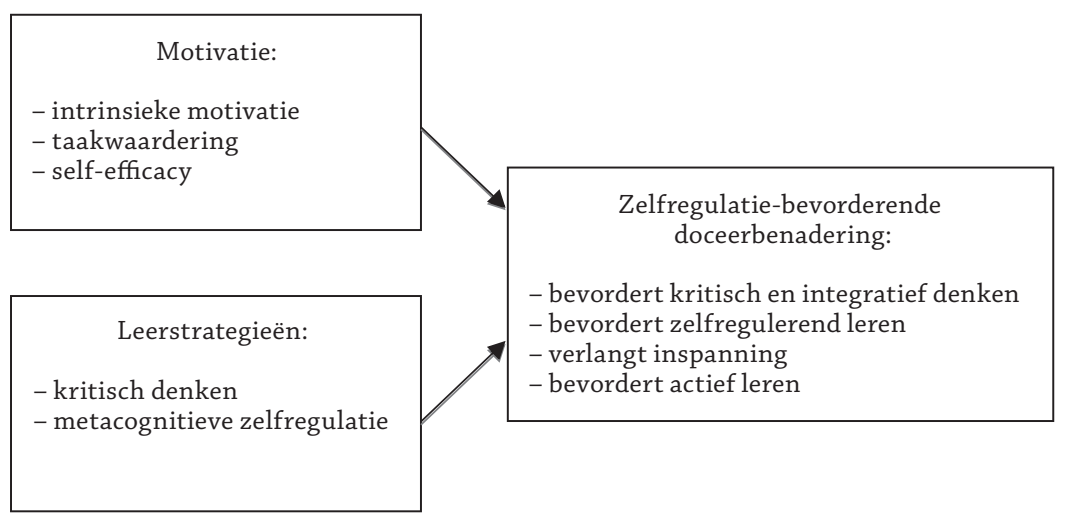

\section{Figuur 1 Verwachtingen relaties motivatie, leerstrategieën en doceerbenaderingsvoorkeur van honoursstudenten}

De doceerbenadering die zelfregulatie bevordert, vertoont veel overeenkomst met wat ervaren honoursdocenten zeggen te doen in hun begeleiding van talent: kritisch denken en actief leren stimuleren, inspanning verlangen en zelfsturend leren bevorderen (Wolfensberger, 2012). De veronderstelling is dan ook dat honoursstudenten vanuit hun intrinsieke motivatie en (meta)cognitieve capaciteiten de voorkeur geven aan een zelfregulatie-bevorderende doceerbenadering.

\section{Onderzoeksvragen}

1 In hoeverre verschillen de motivatie, leerstrategieën en voorkeur voor doceerbenadering tussen honours- en reguliere studenten?

2 In hoeverre voorspellen motivatie en leerstrategie de voorkeur voor doceerbenadering bij honoursstudenten en bij reguliere studenten in het hbo?

\section{Verwachtingen}

Een docent met een zelfregulatiebevorderende benadering lijkt in theorie het beste aan te sluiten bij de behoeften van studenten met een hoge intrinsieke motivatie en hun (meta)cognitieve vaardigheden. De verwachting is dat honoursstudenten, vanuit hun hogere intrinsieke motivatie, taakwaardering, self-efficacy en (meta)cognitieve vaardigheden, de voorkeur zullen geven aan een docent die zelfregulatie bevordert. 


\section{Methode en resultaten}

\section{Procedure en respons}

In april en mei 2011 is een vragenlijst uitgezet onder de honoursstudenten van de Hanzehogeschool ${ }^{1}$, binnen de negen schools die in dat jaar een extracurriculair honoursprogramma startten. De benaderde studenten - allen tweedejaars- en beginnende honoursstudenten - kregen op papier een Nederlands- of Engelstalige (internationale opleidingen) vragenlijst voorgelegd. Voor de Nederlandstalige versie zijn de oorspronkelijke Engelstalige items vertaald en vervolgens voorgelegd aan een native speaker. Alle honoursstudenten zijn, op afspraak met docenten, tijdens honoursbijeenkomsten benaderd. Op dezelfde wijze zijn ook reguliere studenten benaderd tijdens reguliere lessen aan tweedejaarsklassen. Dit resulteerde in 194 ingevulde vragenlijsten, waarvan 60 zijn ingevuld door honoursstudenten (44\% van het totale aantal honoursstudenten op dat moment).

\section{Variabelen en instrumenten}

Dit onderzoek beoogt de verschillen te achterhalen in motivatie en leerstrategieën tussen honours- en reguliere studenten en verkent in hoeverre deze kenmerken te koppelen zijn aan hun voorkeur voor doceerbenadering. Hiertoe is op basis van de veronderstellingen in het theoretisch kader een aantal schalen geselecteerd uit de Motivated Strategies for Learning Questionnaire (MSLQ) (Pintrich et al., 1991) en uit de Instruction Preference Questionnaire (IPQ) (Hativa \& Birenbaum, 2000). Daarnaast zijn etiketten opgesteld met de beschrijvingen van de vier doceerbenaderingen uit de IPQ.

\section{Motivatie}

De motivatie van studenten werd gemeten met vier schalen uit de MSLQ, namelijk intrinsic goal orientation (IGO, 4 items), extrinsic goal orientation (EGO, 4 items), task value (TV, 6 items) en self-efficacy for learning and performance (SELP, 8 items). De betrouwbaarheid (Cronbachs alfa) van de subschalen is in deze studie .67 voor IGO, .71 voor EGO, .79 voor TV en .85 voor SELP. Voorbeelditems zijn 'Hoge cijfers halen geeft mij veel voldoening' (EGO), 'De meeste voldoening haal ik uit het daadwerkelijk doorgronden van de inhoud' (IGO), 'Ik ben zeer geïnteresseerd in de inhoud van mijn studie' (TV) en 'Ik verwacht dat ik goed presteer tijdens mijn studie' (SELP).

\section{(Meta)cognitieve leerstrategieën}

Naast de motivatie van studenten zijn de leerstrategieën in kaart gebracht met behulp van twee schalen uit de MSLQ, namelijk critical thinking (CT, 5 items) en meta-cognitive self-regulation (MSR, 12 items). De Cronbachs alfa van de subschalen is .70 voor CT en .80 voor MSR. Voorbeelditems zijn 'Ik probeer te bepalen of theorieën, interpretaties of conclusies die ik hoor of lees goed onderbouwd zijn met bewijs' (CT) en 'Als ik studeer, stel ik gerichte doelen voor mijzelf' (MSR).

De items over motivatie en leerstrategieën zijn gemeten op een zevenpuntsLikertschaal, oplopend van 'geheel niet' (1) tot 'geheel op mij van toepassing' (7). 
Waar de items in de oorspronkelijke versie van de MSLQ sterk gerelateerd zijn aan de context van een specifiek vak, zijn ze in dit onderzoek algemener geformuleerd voor de context van de gehele studie of voor studeergedrag. Taakwaardering is daarom veralgemeniseerd tot waardering voor de studie.

\section{Doceerbenadering}

De voorkeur voor doceerbenadering is op twee manieren geoperationaliseerd: met etiketten en met items uit een vijftal IPQ-schalen (Hativa \& Birenbaum, 2000). Om een mogelijke voorkeur voor een van de vier doceerbenaderingen (informatieoverdragend; duidelijk-interessant; faciliterend; zelfregulatiebevorderend) vast te kunnen stellen, is voor elk van deze doceerbenaderingen een samenvattend etiket-item opgenomen.

Om deze voorkeur meer in detail te kunnen analyseren en tegelijkertijd de omvang van de vragenlijst te beperken, is een selectie uit de IPQ-schalen gemaakt. Omdat honoursstudenten volgens het theoretische kader de voorkeur geven aan een minder voorgestructureerde leeromgeving, is van de 'duidelijkinteressante' benadering alleen de schaal opgenomen die de voorkeur meet voor een interessante docent. Ook de schaalitems voor de faciliterende en de informatieoverdragende benadering zijn niet opgenomen. De items die horen bij de vier schalen van de doceerbenadering die zelfregulatie bevordert, zijn alle geselecteerd vanwege de veronderstelling die is geformuleerd in de probleemstelling.

De eerste van de vijf geselecteerde IPQ-schalen, presents material in an interesting manner (PMI), maakt onderdeel uit van de 'duidelijke-interessante' benadering en meet de voorkeur voor een docent die materiaal op interessante wijze presenteert. Deze schaal bestaat uit twaalf items en in deze studie is de betrouwbaarheid van de schaal als geheel (Cronbachs alfa) .83. Een voorbeelditem uit deze schaal is 'Mijn voorkeur gaat uit naar een docent die de leerstof op een interessante manier brengt'. Om de voorkeur voor een zelfregulatiebevorderende docent te meten zijn vier schalen van de IPQ gebruikt. De vier schalen, promotes critical thinking and material integration (CTM, 7 items), promotes self-regulated learning (PSL, 3 items), requires effort investment (REI, 3 items) en promotes active learning in class (PAL, 4 items) meten samen de voorkeur voor een zelfregulatiebevorderende docent op een zevenpunts-Likertschaal. De Cronbachs alfa van de subschalen is .82 voor CTM, .70 voor PSL, .64 voor REI en .79 voor PAL. Voorbeelditems zijn 'Mijn voorkeur gaat uit naar een docent die mij aanmoedigt gepresenteerde ideeën kritisch te benaderen' (CTM), 'Mijn voorkeur gaat uit naar een docent die mij stimuleert opdrachten zelfstandig uit te voeren' (PSL), 'Mijn voorkeur gaat uit naar een docent die mij motiveert het beste uit mijzelf te halen' (REI) en 'Mijn voorkeur gaat uit naar een docent die een groot deel van het college besteedt aan discussies tussen studenten over de behandelde leerstof' (PAL).

Zowel de etiket-items als de items uit de IPQ zijn gemeten met een zevenpuntsLikertschaal, oplopend van 'helemaal mee oneens' (1) tot 'helemaal mee eens' (7). 
Tabel 1 Verschillen in motivatie tussen honours- $(n=54)$ en reguliere studenten $(n=110)$

\begin{tabular}{lll}
\hline & $\begin{array}{l}\text { Gemiddelde Honours } \\
\text { (SD) }\end{array}$ & $\begin{array}{l}\text { Gemiddelde Regulier } \\
\text { (SD) }\end{array}$ \\
\hline Intrinsieke motivatie** & $5,7 \mathrm{I}(0,74)$ & $5,18(0.86)$ \\
Extrinsieke motivatie & $5,0 \mathrm{I}(\mathrm{I}, 23)$ & $4,67(\mathrm{I}, 05)$ \\
Studiewaardering* & $5,75(0,68)$ & $5,48(0,74)$ \\
Self-efficacy** & $5,77(0,64)$ & $5,05(0,8 \mathrm{I})$ \\
\hline
\end{tabular}

$* *=p<.01 ; *=p<.05$

\section{Analyses}

Het eerste doel van deze studie was om de verschillen te achterhalen tussen honours- en reguliere studenten in motivatie, leerstrategieën en voorkeuren voor doceerbenadering. Daartoe zijn de gemiddelde scores voor beide groepen berekend en getoetst met een t-test voor onafhankelijke groepen. Alle toetsen zijn tweezijdig uitgevoerd $(\alpha=.05)$.

Ook onderzocht deze studie de relatie tussen motivatie en leerstrategieën enerzijds en doceerbenaderingsvoorkeur anderzijds, voor zowel honours- als reguliere studenten. Voor beide groepen zijn afzonderlijke lineaire regressieanalyses uitgevoerd met motivatie en leerstrategieën als onafhankelijke variabelen en de voorkeuren voor doceerbenadering als afhankelijke variabelen.

Van de 194 ingevulde vragenlijsten hadden 50 respondenten een of meer ontbrekende waarden op een van de items behorende bij de schalen voor doceerbenadering, motivatie en leerstrategie of op een van de vier etiket-items. Bij de schalen die bestaan uit vijf of meer items, is ervoor gekozen om één ontbrekende waarde toe te staan. Van de 50 respondenten met missende waarden bleven daarna 20 behouden. De uiteindelijke analyses zijn gebaseerd op 164 respondenten, waarvan 54 (33\% van de respondenten) een honoursprogramma volgden.

\section{Resultaten}

\section{Verschillen in motivatie}

Tabel 1 toont de verschillen tussen honours- en reguliere studenten voor de verschillende aspecten van motivatie. De honoursstudenten scoren zichzelf hoger op intrinsieke motivatie ( $t=3,91, d f=162$ ), op taakwaardering en self-efficacy ( $t=$ $2,26, d f=162$ respectievelijk $t=5,73, d f=162$ ). De hogere score van de honoursstudenten ten opzichte van de reguliere studenten op extrinsieke motivatie is niet significant. 
Tabel 2 Verschillen in leerstrategie tussen honours- $(n=54)$ en reguliere studenten $(n=110)$

\begin{tabular}{lll}
\hline & $\begin{array}{l}\text { Gemiddelde Honours } \\
\text { (SD) }\end{array}$ & $\begin{array}{l}\text { Gemiddelde Regulier } \\
\text { (SD) }\end{array}$ \\
\hline Kritisch denken* & $4,60(I, 06)$ & $4,20(I, 06)$ \\
Metacognitieve zelfregulatie** & $4,79(0,68)$ & $4,43(0,74)$ \\
\hline
\end{tabular}

$* *=\mathrm{p}<.01 ; *=\mathrm{p}<.05$

Tabel 3 Verschillen in doceerbenaderingsvoorkeur (etiketten) tussen honours$(n=54)$ en reguliere studenten $(n=110)$

\begin{tabular}{lll}
\hline & $\begin{array}{l}\text { Gemiddelde Honours } \\
\text { (SD) }\end{array}$ & $\begin{array}{l}\text { Gemiddelde Regulier } \\
\text { (SD) }\end{array}$ \\
\hline Informatie-overdragend & $4,6 \mathrm{I}(\mathrm{I}, 55)$ & $4,79(\mathrm{I}, 43)$ \\
Duidelijk-interessant & $5,74(\mathrm{I}, 23)$ & $6,10(0,90)$ \\
Faciliterend** & $4,8 \mathrm{I}(\mathrm{I}, 52)$ & $5,7 \mathrm{I}(\mathrm{I}, 05)$ \\
Zelfregulatiebevorderend** & $5,50(\mathrm{I}, 2 \mathrm{I})$ & $4,85(\mathrm{I}, 3 \mathrm{I})$ \\
\hline
\end{tabular}

** $=\mathrm{p}<.01$

Verschillen in leerstrategieën

In tabel 2 zijn de verschillen te zien tussen honours- en reguliere studenten voor de verschillende leerstrategieën. De honoursstudenten scoren zichzelf zoals verwacht significant hoger op kritisch denken $(t=2,31, d f=162)$ en op metacognitieve zelfregulatie ( $t=3.01, d f=162)$.

Verschillen in voorkeur voor doceerbenadering (etiketten)

Tabel 3 verduidelijkt het verschil tussen honours- en reguliere studenten in doceerbenaderingsvoorkeur. Zowel honours- als reguliere studenten kennen de hoogste gemiddelde score toe aan het etiket dat de 'duidelijk-interessante' doceerbenadering beschrijft. Honoursstudenten hebben daarnaast een sterke voorkeur voor een doceerbenadering die zelfregulatie bevordert $(t=3,09, d f=162)$. Reguliere studenten daarentegen prefereren naast de 'duidelijk-interessante' doceerbenadering de faciliterende doceerbenadering het meest $(t=-3,89, d f=$ 79). Voor de informatieoverdragende benadering is geen significant verschil aangetoond tussen honours- en reguliere studenten. Bij beide groepen studenten krijgt deze benadering de laagste waardering.

Verschillen in voorkeur voor doceerbenadering (schalen)

Tabel 4 toont de verschillen tussen honours- en reguliere studenten voor de schalen die de voorkeur meten voor een interessante docent (PMI) en voor de zelfregulatiebevorderende docent (CTM, PSL, REI en PAL). De honoursstudenten hebben een significant grotere voorkeur dan de reguliere studenten voor docenten die kritisch en integratief denken bevorderen (CTM; $t=2,09, d f=162$ ) en 
Tabel $4 \quad$ Verschillen in doceerbenaderingsvoorkeur (schalen) tussen honours$(n=54)$ en reguliere studenten $(n=110)$

\begin{tabular}{|c|c|c|}
\hline & $\begin{array}{l}\text { Gemiddelde Honours } \\
\text { (SD) }\end{array}$ & $\begin{array}{l}\text { Gemiddelde Regulier } \\
\text { (SD) }\end{array}$ \\
\hline $\begin{array}{l}\text { Presenteert materiaal op interessante } \\
\text { wijze (PMI) }\end{array}$ & $5,78(0,73)$ & $5,88(0,6 I)$ \\
\hline $\begin{array}{l}\text { Bevordert kritisch en integratief den- } \\
\text { ken (CTM)* }\end{array}$ & $5,22(0,95)$ & $4,93(0,8 I)$ \\
\hline Bevordert zelfregulerend leren (PSL) & $4,45(1,22)$ & $4,22(1,17)$ \\
\hline Verlangt inspanning (REI) & $5,28(I, 15)$ & $5,20(1,02)$ \\
\hline Bevordert actief leren (PAL)* & $4,00(1,35)$ & $3,67(1,08)$ \\
\hline
\end{tabular}

$*=\mathrm{p}<.05$

voor docenten die actief leren bevorderen (PAL; $t=1,68, d f=162$ ). De docent die materiaal op een interessante wijze presenteert (PMI) heeft bij beide groepen studenten de sterkste gemiddelde voorkeur.

Relatie van motivatie en leerstrategie met voorkeur voor doceerbenadering (etiketten) Tabellen 5 en 6 tonen de resultaten van de regressieanalyse voor respectievelijk de honours- en reguliere studenten met de vier etiket-items over de doceerbenaderingen als afhankelijke variabele en motivatie en leerstrategieën als onafhankelijke variabelen.

De motivatie en leerstrategieën van de honoursstudenten verklaren gezamenlijk de meeste variantie in de voorkeur voor een zelfregulatiebevorderende doceerbenadering (41\%), $18 \%$ van de variantie in de voorkeur voor een informatieoverdragende doceerbenadering, $13 \%$ van de variantie in de voorkeur voor een 'duidelijk-interessante' benadering en $3 \%$ van de variantie in de voorkeur voor een faciliterende benadering. Extrinsieke motivatie blijkt bij honoursstudenten een significante positieve voorspeller te zijn van de voorkeur voor een informatieoverdragende doceerbenadering $(\beta=0.32)$. De leerstrategie "kritisch denken van honoursstudenten' blijkt daarnaast een significante voorspeller te zijn van de voorkeur voor een zelfregulatiebevorderende docent $(\beta=0.37)$.

De motivatie en leerstrategieën van de reguliere studenten verklaren gezamenlijk de meeste variantie in de voorkeur voor een zelfregulatiebevorderende benadering (22\%), $15 \%$ van de variantie in de voorkeur voor een 'duidelijk-interessante' benadering, $9 \%$ van de variantie in de voorkeur voor een faciliterende benadering en $4 \%$ van de variantie in de voorkeur voor een informatieoverdragende doceerbenadering.

Extrinsieke motivatie en taakwaardering blijken bij reguliere studenten (tabel 6) significante positieve voorspellers te zijn van de voorkeur voor een 'duidelijkinteressante’ doceerbenadering ( $\beta=0.24$ respectievelijk $\beta=0.35$ ). Daarnaast 
Tabel $5 \quad$ Voorkeursvoorspelling van doceerbenadering (etiketten) door motivatie en leerstrategie van honoursstudenten $(n=54)$

\begin{tabular}{|c|c|c|c|c|c|c|c|c|}
\hline & \multicolumn{2}{|c|}{$\begin{array}{l}\text { Informatie- } \\
\text { overdragend }\end{array}$} & \multicolumn{2}{|c|}{$\begin{array}{l}\text { Duidelijk-inte- } \\
\text { ressant }\end{array}$} & \multicolumn{2}{|c|}{ Faciliterend } & \multicolumn{2}{|c|}{$\begin{array}{l}\text { Zelfregulatie } \\
\text { bevorderend }\end{array}$} \\
\hline & $\beta$ & SE & $\beta$ & SE & $\boldsymbol{\beta}$ & SE & $\beta$ & SE \\
\hline $\begin{array}{l}\text { Intrinsieke moti- } \\
\text { vatie }\end{array}$ &, 134 & ,44I &,- 188 & ,363 &,- 158 & ,47I & 213 & ,293 \\
\hline $\begin{array}{l}\text { Extrinsieke moti- } \\
\text { vatie }\end{array}$ &, $315 *$ & , 187 &, 147 &, 153 &,- 026 & , 199 & ,028 &, 124 \\
\hline Studiewaardering &,- 229 & ,459 & ,297 & ,377 &, 120 & ,490 &,- 056 & ,305 \\
\hline Self-efficacy & , 138 & ,383 &,- 068 & ,315 &,- 024 & ,409 & ,083 &, 254 \\
\hline Kritisch denken &,- 257 & ,229 &,- 157 & , 188 & 129 & 245 & ,374** & , 152 \\
\hline $\begin{array}{l}\text { Metacognitieve } \\
\text { zelfregulatie }\end{array}$ & , 191 & ,377 & ,099 & ,310 & ,098 & ,403 &, 188 &, 250 \\
\hline
\end{tabular}

$* *=p<.01 ; *=p<.05$

Tabel 6 Voorkeursvoorspelling voor doceerbenadering (etiketten) door motivatie en leerstrategie van reguliere studenten $(n=110)$

\begin{tabular}{|c|c|c|c|c|c|c|c|c|}
\hline & \multicolumn{2}{|c|}{$\begin{array}{l}\text { Informatie- } \\
\text { overdragend }\end{array}$} & \multicolumn{2}{|c|}{$\begin{array}{l}\text { Duidelijk-inte- } \\
\text { ressant }\end{array}$} & \multicolumn{2}{|c|}{ Faciliterend } & \multicolumn{2}{|c|}{$\begin{array}{l}\text { Zelfregulatie- } \\
\text { bevorderend }\end{array}$} \\
\hline & $\beta$ & SE & $\beta$ & SE & $\beta$ & SE & $\beta$ & SE \\
\hline $\begin{array}{l}\text { Intrinsieke moti- } \\
\text { vatie }\end{array}$ & ,018 & ,201 &,- 128 &, 118 &,- 001 & , I43 &, 166 & , 165 \\
\hline $\begin{array}{l}\text { Extrinsieke moti- } \\
\text { vatie }\end{array}$ & , 106 &, 161 &, $235 *$ & ,095 & , 199 &, 115 &,- 194 &, 132 \\
\hline Studiewaardering & ,056 & ,236 &, $350 * *$ &, 138 &, $268 *$ & , 168 & , 170 & , 194 \\
\hline Self-efficacy &,- 031 &, 234 &,- 103 &, 138 &,$- \mid 144$ & , 167 &,- 034 & , 193 \\
\hline Kritisch denken &,- 173 & , 168 & ,028 & ,099 & ,045 &, 120 & , 187 & , I38 \\
\hline $\begin{array}{l}\text { Metacognitieve } \\
\text { zelfregulatie }\end{array}$ & ,058 &, 263 &,- 017 &, 155 &,- 068 & , 188 & , 176 &, 217 \\
\hline
\end{tabular}

** $=\mathrm{p}<.01$; $* \mathrm{p}<.05$

blijkt de taakwaardering van reguliere studenten ook een significante voorspeller van de voorkeur voor een faciliterende doceerbenadering $(\beta=0.27)$.

Relatie van motivatie en leerstrategie met voorkeur voor doceerbenadering (schalen) Tabellen 7 en 8 bevatten de resultaten van de regressieanalyses voor respectievelijk de honours- en reguliere studenten met als afhankelijke variabele de voorkeur voor doceerbenadering en als onafhankelijke variabelen motivatie en leerstrategieën.

De motivatie en leerstrategieën van de honoursstudenten verklaren gezamenlijk de meeste variantie in de voorkeur voor CTM (47\%), 33\% van de variantie in PMI, $32 \%$ in PSL, $24 \%$ in REI en $17 \%$ van de variantie in PAL. De voorkeur voor een 
docent die materiaal op interessante wijze presenteert blijkt significant positief voorspeld te worden door taakwaardering $(\beta=0.60)$. De voorkeur voor een docent die kritisch denken bevordert, wordt eveneens positief voorspeld door taakwaardering $(\beta=0.40)$, maar negatief voorspeld door extrinsieke motivatie $(\beta=-0.27)$. Tot slot wordt de voorkeur van honoursstudenten voor een docent die inspanning verlangt negatief voorspeld door de leerstrategie kritisch denken $(\beta=-0.35)$.

De motivatie en leerstrategieën van de reguliere studenten verklaren gezamenlijk de meeste variantie in de voorkeur voor CTM (39\%), 26\% in PSL, 25\% in REI, $24 \%$ van de variantie in PMI en $21 \%$ van de variantie in PAL. Intrinsieke motivatie en taakwaardering blijken een significante voorspeller te zijn van een voorkeur voor een docent die materiaal op interessante wijze presenteert $(\beta=0.23$ respectievelijk $\beta=0.36$ ). De voorkeur voor een docent die kritisch denken bevordert, wordt positief voorspeld door intrinsieke motivatie en taakwaardering $(\beta=0.26$ respectievelijk $\beta=0.20)$ en door de leerstrategie kritisch denken $(\beta=0.44)$. Er is tevens een significante voorspellende waarde van intrinsieke motivatie en van kritisch denken voor een voorkeur voor een docent die zelfregulerend leren bevordert $(\beta=0.41$ respectievelijk $\beta=0.23$ ). Daarnaast wordt de voorkeur voor een docent die inspanning verlangt positief voorspeld door intrinsieke motivatie $(\beta=0.32)$ en door taakwaardering $(\beta=0.26)$. Tot slot voorspelt de leerstrategie kritisch denken de voorkeur voor een docent die actief leren bevordert $(\beta=0.29)$. 


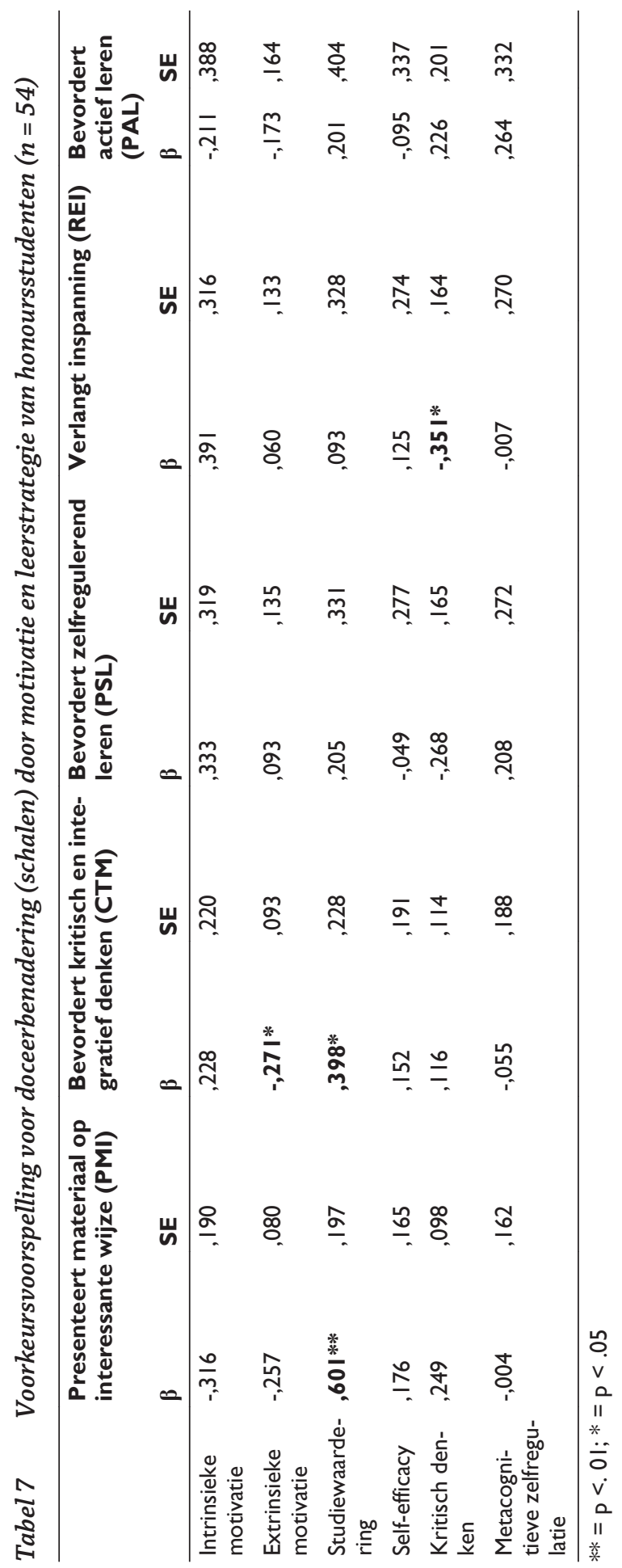




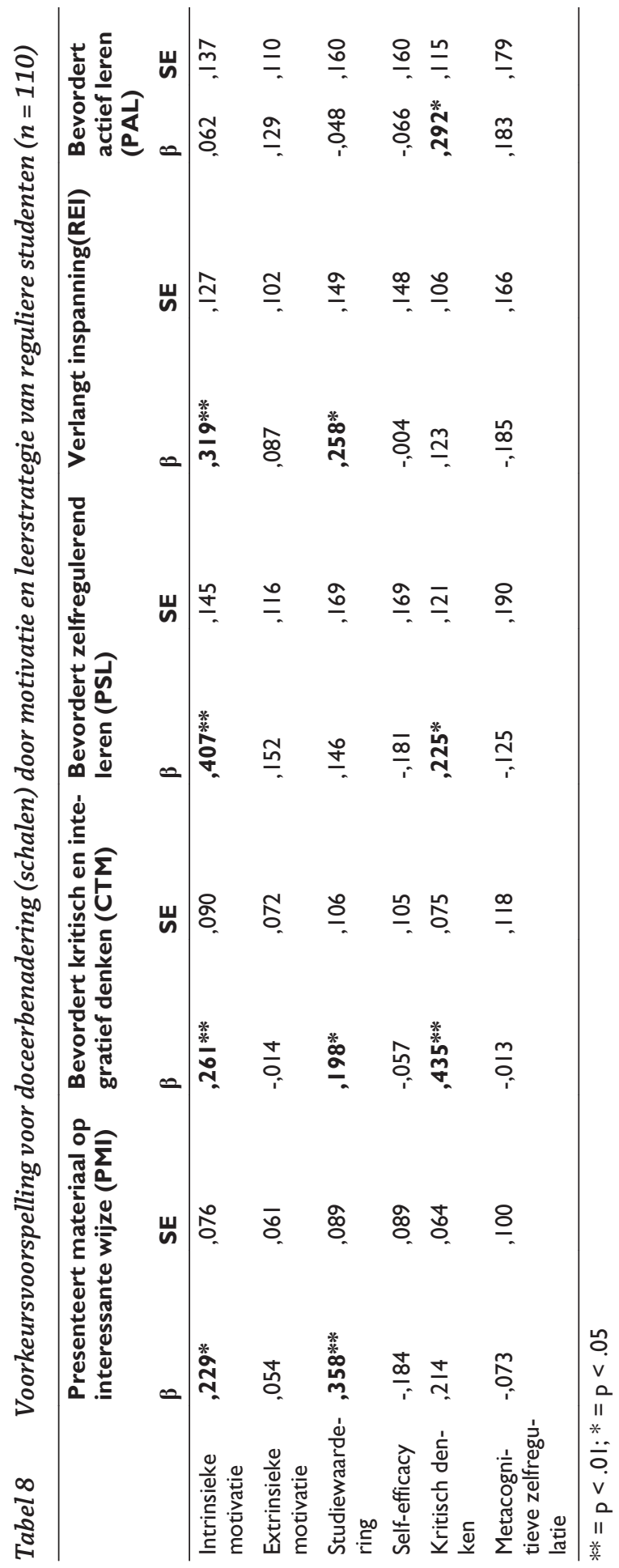




\section{Conclusie en discussie}

De verwachting op basis van het theoretisch kader was dat honoursstudenten een voorkeur zullen hebben voor een docent die zelfregulatie bevordert, vanuit hun hogere intrinsieke motivatie, hun hogere taakwaardering, self-efficacy en (meta)cognitieve vaardigheid.

\section{Verschillen in motivatie, leerstrategie en voorkeur voor doceerbenadering}

Honoursstudenten scoren zichzelf zoals verwacht hoger dan reguliere studenten op intrinsieke motivatie, waardering voor de studie en self-efficacy. Naast deze verschillen in motivatie zeggen honoursstudenten kritischer na te denken over de aangeboden stof en vaker zelfregulerende strategieën toe te passen. Ze blijken tot slot een andere doceerbenaderingsvoorkeur te hebben dan reguliere studenten. Reguliere studenten prefereren de 'duidelijk-interessante' en de faciliterende doceerbenadering, terwijl honoursstudenten een 'duidelijke-interessante' en een zelfregulatiebevorderende benadering prefereren. $\mathrm{Zij}$ geven binnen die laatste benadering een grotere voorkeur aan docenten die kritisch en integratief denken stimuleren en die actief leren bevorderen. Motivatie en leerstrategieën van hbohonoursstudenten blijken dus overeen te komen met wat er in de literatuur bekend is over getalenteerde studenten in het hoger onderwijs.

\section{Invloed van motivatie en leerstrategie op voorkeur voor doceerbenadering}

Hoewel honoursstudenten zichzelf hoger scoren op motivatie en leerstrategieën dan reguliere studenten, levert deze studie geen overtuigend bewijs dat deze kenmerken hun voorkeur beïnvloeden voor een docent die zelfregulatie bevordert. Een hogere score op intrinsieke motivatie blijkt de voorkeur voor een specifiek type doceerbenadering niet te kunnen voorspellen. De mate waarin een honoursstudent zijn studie waardeert, beïnvloedt bij de honoursstudenten wel de voorkeur voor een zelfregulatiebevorderende docent die kritisch denken stimuleert, maar doet dat ook voor een docent die het materiaal op interessante wijze presenteert. Een hogere score op kritisch denken lijkt - tegen de verwachting in - de voorkeur voor docenten die inspanning verlangen negatief te beïnvloeden. En hoewel de typering van de informatieoverdragende docent de laagst gewaardeerde onder de vier doceerbenaderingen bleek, wordt deze voorkeur positief voorspeld door extrinsieke motivatie. Intrinsieke motivatie en waardering voor de studie blijken bij de reguliere studentengroep de voorkeur voor een zelfregulatiebevorderde benadering overigens wel te voorspellen.

\section{Mogelijke implicaties voor honoursonderwijs}

Hoe hoger de waarde die honoursstudenten aan hun studie hechten, hoe hoger hun voorkeur voor een docent die kritisch denken stimuleert: dit lijkt dus een geschikte doceerstrategie voor honoursonderwijs. Een hogere score op waardering voor de studie voorspelt daarnaast bij zowel de honours- als de reguliere studenten een positief effect op de voorkeur voor een docent die materiaal op interessante wijze presenteert. Deze voorkeur betekent wellicht dat een student die veel waarde hecht aan zijn studie, vindt dat een interessante docent deze waarde 
nog eens extra vergroot. Volgens Entwistle \& Tait (1990) onderscheiden studenten met een beroepsmatige focus zich van studenten met een academische benadering: de laatste groep zou meer behoefte hebben aan intellectuele uitdaging en (zelf)studie. Hbo-honoursstudenten zouden vanwege de nadruk in de programma's op professionele excellentie een meer beroepsmatige dan academische focus kunnen hebben. Wellicht hechten ze daarom meer belang aan een interessante docent die helder maakt wat interessant, belangrijk en nuttig is voor het beroep.

Achterberg (2005) en Kaczvinsky (2007) benadrukken dat er geen blauwdruk voor honoursstudenten bestaat; de aard van de motivatie kan variëren per student en per taak. Een honoursstudent zal niet per definitie altijd alleen maar intrinsiek gemotiveerd zijn. Pintrich et al. (1993) benadrukken dat extrinsieke en intrinsieke motivatie elkaar kunnen versterken ten gunste van zelfregulatie. Docenten doen er dus goed aan om de aard van de motivatie van (beginnende) honoursstudenten te blijven monitoren: wanneer deze meer extrinsiek georiënteerd is, kan er wellicht eerder disharmonie optreden tussen de strategieën van de student en een eventuele zelfregulatiebevorderende benadering door de docent. Daarmee is overigens niet gezegd dat de zelfregulatiebevorderende docent zijn benadering zou moeten aanpassen: hij mag er alleen niet automatisch van uitgaan dat elke hbo-honoursstudent deze benadering al in de beginfase van het honoursprogramma prefereert. Uitleg over de redenen achter de gekozen zelfregulatiebevorderende benadering zou wellicht tot meer acceptatie, of toch tenminste tot herkenning van eventuele leerobstakels door de honoursstudent kunnen leiden.

\section{Richtingen voor vervolgonderzoek}

Deze studie stelde zich ten doel om de kenmerken en doceerbenaderingsvoorkeur van honours- en reguliere studenten in het hbo te achterhalen, om zo bij te dragen aan de inzichten in effectieve doceerstrategieën voor gemotiveerde en getalenteerde studenten in het hoger onderwijs. Vervolgonderzoek op basis van deze resultaten kan ook voor beleidsmakers binnen het hbo interessant zijn, om bijvoorbeeld selectieprocedures voor honoursprogramma's aan te scherpen. De uitkomsten van deze verkennende studie roepen nieuwe vragen op die dat inzicht kunnen verdiepen.

Zo kan de hogere zelfscore van honoursstudenten op waardering voor de studie opgevat worden als de aanleiding om een honoursprogramma te volgen, maar het kan ook betekenen dat honoursstudenten juist dankzij het honoursprogramma de studie meer waarderen. Vervolgonderzoek naar het effect van de beleefde meerwaarde van honoursprogramma's op waardering voor de studie in het algemeen zou meer licht op oorzaak en gevolg kunnen bieden.

Het grootste verschil in zelfperceptie laten honours- en reguliere studenten zien voor self-efficacy: honoursstudenten zeggen, conform Kaczvinsky (2007), meer vertrouwen te hebben in hun vaardigheden om de studie met goed gevolg te volbrengen. Het is interessant om te achterhalen of een hoge self-efficacy een voorspeller is voor deelname aan een honoursprogramma en dus een bevestiging van 
het benodigde vertrouwen in eigen kunnen om de uitdaging van een honoursprogramma aan te durven. Een hoge self-efficacy kan echter ook het gevolg zijn van deelname aan het programma: Achterberg (2005, p. 79) benoemt terecht het zogenoemde Pygmalion-effect 'where a faculty member's beliefs about a student create the behaviors and abilities that the educator had anticipated from the student, i.e., a self-fulfilling prophecy', als mogelijke verklaring voor een dergelijk verschil.

Ook de beperkingen van deze verkennende studie bieden richting voor vervolgonderzoek. De vragenlijst is alleen afgenomen onder tweedejaars hbo-honours- en reguliere studenten, omdat er op dat moment nauwelijks ouderejaars honoursstudenten waren. De groep honoursstudenten had op dat moment dus pas een kwart van het honoursprogramma doorlopen. Honours- en reguliere studenten hebben bij aanvang van hun hoofdfaseprogramma waarschijnlijk andere voorkeuren voor doceerbenaderingen dan aan het eind ervan. Groeiende taakvolwassenheid kan bijvoorbeeld leiden tot een grotere behoefte aan autonomie en een andere doceerbenaderingsvoorkeur. Afname van de vragenlijst in een latere fase van de studie kan verhelderen of het verschil in de doceerbenaderingsvoorkeur voor reguliere en honoursstudenten varieert. Daarnaast is eventuele uitval in een later stadium buiten beschouwing gelaten. Vervolgonderzoek kan uitwijzen of studenten het honoursprogramma ook daadwerkelijk hebben afgerond en of succes in het honoursprogramma is gerelateerd aan motivatie, leerstrategie en geprefereerde doceerbenadering. Dit kan aanvullende inzichten geven voor het beleid rond selectieprocedures van honoursstudenten. Zo kan het interessant zijn om te achterhalen of die honoursstudenten die vanuit een hogere extrinsieke motivatie de voorkeur geven aan een informatieoverdragende docent, in staat zijn geweest om ondanks deze 'theoretische mismatch' het honoursprogramma af te ronden.

Taakwaardering is in dit onderzoek veralgemeniseerd tot waardering voor de studie. Dat maakt ook de onderzoeksresultaten algemener. Het kan interessant zijn om te achterhalen of honoursstudenten in hun reguliere programma een andere voorkeur voor doceerbenadering hebben dan binnen het honoursprogramma en of dat verklaard kan worden vanuit verschillen in taakwaardering.

Ook de resultaten binnen de groep honoursstudenten roepen nieuwe vragen op. Zo was vanwege het verkennende karakter van het onderzoek en de beperkte omvang van de groep honoursstudenten een multiple group-analyse nog niet opportuun. Een dergelijke analyse kan de verschillen in de relaties tussen de variabelen voor beide groepen toetsen en verhelderen.

Ten slotte zijn als onafhankelijke variabelen alleen motivatie en leerstrategieën van honoursstudenten onderzocht. Kenmerken als studieprestaties, type hboopleiding, leeftijd, geslacht en persoonlijkheidskenmerken zoals consciëntieusheid en emotionele stabiliteit zijn niet meegenomen in analyses. Voor een vollediger beeld van de specifieke behoeften van hbo-honoursstudenten voor wat betreft hun docenten is uitbreiding van de vragenlijst, de onderzoekspopulatie en de analysemethodiek wenselijk. 


\section{Noot}

1 Het onderzoek was onderdeel van een UHG-samenwerkingsproject tussen de Rijksuniversiteit Groningen en de Hanzehogeschool Groningen. Voor de totstandkoming van het onderzoeksinstrument is dank verschuldigd aan de projectleden Ellen Jansen, Marjon Fokkens-Bruinsma en Margreet Schurer.

\section{Referenties}

Achterberg, C. (2005). What is an honors student? Journal of the NCHC, 6 (1), 75-83.

Biggs, J. (1996). Enhancing teaching through constructive alignment. Higher Education, 32(3), 347-364.

Entwistle, N.J., \& Tait, H. (1990). Approaches to learning, evaluations of teaching, and preferences for contrasting academic environments. Higher Education, 19 (2), 169-194.

Hativa, N., \& Birenbaum, M. (2000). Who prefers what? Disciplinary differences in students' preferred approaches to teaching and learning styles. Research in Higher Education, 41(2), 209-236.

Kaczvinsky, D.P. (2007). What is an honors student? A Noel-Levitz survey. Journal of the NCHC, 8(2), 87-95.

Pintrich, P.R., Smith, D.A.F., Garcia, T., \& McKeachie, W.J. (1991). A manual for the use of the Motivated Strategies for Learning Questionnaire (MSLQ). Ann Arbor, MI: University of Michigan.

Pintrich, P.R., Smith, D.A.F., Garcia, T., \& McKeachie, W. (1993). Reliability and predictive validity of the Motivated Strategies for Learning Questionnaire (MSLQ). Educational and Psychological Measurement, 53, 801-813.

Renzulli, J. (2008). Redefining the role of gifted education for the twenty-first century. Vancouver: Keynote address World Conference World Council for gifted and talented children.

Ryan, R.M., \& Deci, E.L. (2000). Self-determination theory and the facilitation of intrinsic motivation, social development, and wellbeing. American Psychologist, 55, 68-78.

Scager, K. (2008). Vragen talentvolle studenten ander onderwijs? Onderzoek van Onderwijs, 37, 66-69.

Sternberg, R.J. (2001). Giftedness as developing expertise: a theory of the interface between high abilities and achieved excellence. High ability studies, 12(2), 159-179.

Trigwell, K., Prosser, M., \& Waterhouse, F. (1999). Relations between teachers' approaches to teaching and students' approaches to learning. Higher Education, 37, 57-70.

Wolfensberger, M.V.C., \& Offringa, G.J. (2012). Qualities Honors Students Look for in Faculty and Courses Revisited. Journal of the NCHC, 13(2), 171-182.

Wolfensberger, M.V.C. (2012). Teaching for excellence. Honors Pedagogies revealed. Münster: Waxmann.

Zimmerman, B.J. \& Schunk, D.H. (2008). An essential dimension of self-regulated learning. In B.J. Zimmerman \& D.H. Schunk (Eds.), Motivation and self-regulation: Theory, research, and applications (pp. 1-31). New York: Routledge 